\title{
Research on evaluation index system of warehouse management based on improved AHP
}

\author{
MeiTao ${ }^{1,}$,, WenBin ${ }^{1, b}$ XuHongying ${ }^{1, c}$ \\ ${ }^{1}$ Xinxing Cathay International Group Co., Ltd. research institute (technical center) Beijing., china
}

Keywords: List the keywords covered in your paper. These keywords will also be used by the publisher to produce a keyword index.

Abstract. Facing the fierce market competition, more and more enterprises are focusing on product logistics. As an important link in the logistics system, warehouse management is under great pressure. In this paper, AHP is used to evaluate the warehouse management, and the evaluation value of each index is given.

\section{Introduction}

With the improvement of production technology and management technology, the competition between the enterprises becomes more intense, people gradually found that enterprise in lower production cost competition seems to have come to an end, the product quality is only the key of an enterprise could enter the market to competition. At this moment, the focus of the competition start from production field to non-production areas, turned to the past those scattered, isolated, is regarded as the auxiliary part and ignored, such as transportation, storage, packaging, loading and unloading, distribution processing, and other areas of the logistics activities. People began to study how to reduce costs in these areas, improve service quality and create "a third source of profit". Therefore, warehousing management, as one of the important projects, is separated from the traditional production and sales activities of the enterprise and becomes an independent branch.

Many scholars have studied this. The research field of foreign warehouse management is medical industry, retail industry, etc. Cook, for example, DeBree such as the warehouse management application in the medical industry, expounds the five tools of warehouse management, customer relationship management, technology, forecasting, outsourcing, cost management, found that the lack of system integration of supply chain function hindered the application of the theories and methods of supply chain management in service industry practice. Breidbach and Reefke used the management consulting industry as an example to study the formation and coordination mechanism of warehouse management. Wei-hua liu etc. Thought warehouse management described in physical products as the center of manufacturing industry supply chain, but the service description of the supply chain is a service industry, service around product to carry out the formation of the supply chain. According to cheng jiangang, li congdong summarized the connotation of warehousing management given by the scholars as follows: one kind of service supply chain refers to those links and activities that involve the intangible service in the traditional supply chain.

\section{Model building}

Analytic hierarchy process (ahp) is a kind of important method to ascertain the weight of evaluation index, but does not meet the consistency conditions has been the analytic hierarchy process $(\mathrm{ahp})^{1}$, the problems facing flood flow, ju-liang $\mathrm{jin}^{2}, \mathrm{M}$ a W a $\mathrm{Y}^{3}$, eigenvector method using genetic algorithm to improve the consistency of analytic hierarchy process (ahp), but did not fundamentally change the analytic hierarchy process (ahp), a defect. The G1 ${ }^{4}$ method does not need to construct a judgment matrix. The importance of the index can be determined by the following formula, and the weight of each index can be determined. The following is the G1 method to determine the index weight step.

(1)Determine the importance of indicators 
Using the $x_{i}(i=1,2 \ldots n)$ magnitude of the importance of the indicators, Remember $x_{i} \geq x_{j}$ that the importance of representation $x_{i}$ and $x_{j}$ is greater than or equal to both. Sort of the importance of $x_{i}$, Remember $x_{i}^{*}$ is the first index after sorting, So there are $x_{1}^{*}>x_{2}{ }_{2} \ldots>x_{n}^{*}$, This is the formula for sorting $x_{i}$ by importance.

(2) The relative importance of two indexes is given

The magnitude of the magnitude of $x_{k-1}$ and $x_{k}$ is measured in $(k=2,3 \ldots n)$, The value of $x_{k-1}$ and $x_{k}$ is shown in table 2 of the assignment of $r_{k}$.

Table 1 comparison between indicators based on G1 method

\begin{tabular}{ccccccc}
\hline $\begin{array}{c}\text { Degree } \\
\text { of } \\
\begin{array}{c}\text { importan } \\
\text { ce }\end{array}\end{array}$ & $\begin{array}{c}\text { Equally } \\
\text { importan } \\
\mathrm{t}\end{array}$ & $\begin{array}{c}\text { weak } \\
\text { importan } \\
\text { ce }\end{array}$ & $\begin{array}{c}\text { General } \\
\text { importan } \\
\mathrm{t}\end{array}$ & $\begin{array}{c}\text { Obviousl } \\
\mathrm{y} \\
\text { importan } \\
\mathrm{t}\end{array}$ & $\begin{array}{c}\text { Highly } \\
\text { importan } \\
\mathrm{t}\end{array}$ & $\begin{array}{c}\text { absolute } \\
\text { importan } \\
\text { ce }\end{array}$ \\
\hline$r_{i}$ & 1.0 & 1.2 & 1.4 & 1.6 & 1.8 & 2.0 \\
\hline
\end{tabular}

(3) The calculation of weight coefficient

According to the literature [5], If the rational assignment that the expert gives $r_{k}$ satisfies $r_{k-1} * r_{k}>1$, then $w_{n}=\left[1+\sum_{k=2}^{n} \prod_{i=k}^{n} r_{k}\right], w_{k-1}^{*}=w_{k}^{*} * r_{k}, k=(n, n-1 \ldots 2) 。$

\section{Indicator system determination}

The level of material storage is mainly the storage of materials and the management of equipment, including material damage rate and equipment damage rate. The data collection of this index is mainly qualitative and evaluated by questionnaire. Efficiency management refers to the rational management of the warehouse to improve work efficiency and the effect of including warehouse utilization, material transportation efficiency, utilization rate of equipment and personnel factors, three factors belong to qualitative indicators. The level of cost control refers to the capital and safe production cost of the material overstock, including the material turnover rate, credit default rate and cash flow capacity. Informatization level is mainly refers to the warehouse informatization degree, whether the warehouse operation in all kinds of homework, which include optimizing organizational ability, fine service capacity, automation ability three aspects factors. The following table shows.

Table 2 Storage evaluation index system.

\begin{tabular}{|c|c|c|}
\hline Level indicators & Secondary indicators & Third grade indicators \\
\hline \multirow{12}{*}{$\begin{array}{c}\text { Warehouse management } \\
\text { evaluation }\end{array}$} & \multirow{3}{*}{ Material storage level } & Material damage rate \\
\hline & & Equipment failure rate \\
\hline & & Maintenance frequency \\
\hline & \multirow{3}{*}{ Efficiency management level } & Warehouse utilization \\
\hline & & Material transport efficiency \\
\hline & & Equipment and personnel utilization. \\
\hline & \multirow{3}{*}{ Cost control level } & Material turnover. \\
\hline & & Credit default rate \\
\hline & & Cash flow \\
\hline & \multirow{3}{*}{ Informatization level } & Optimize the organization \\
\hline & & Fine service \\
\hline & & automation \\
\hline
\end{tabular}




\section{Evaluation model design and calculation}

Table 3 A-B judgment matrix table.

\begin{tabular}{|c|c|c|c|c|}
\hline $\mathrm{A}$ & $\mathrm{B}_{1}$ & $\mathrm{~B}_{2}$ & $\mathrm{~B}_{3}$ & $\mathrm{~B}_{4}$ \\
\hline $\mathrm{B}_{1}$ & 1 & 3 & $1 / 3$ & 4 \\
\hline $\mathrm{B}_{2}$ & $1 / 3$ & 1 & $1 / 5$ & 3 \\
\hline $\mathrm{B}_{3}$ & 3 & 5 & 1 & 6 \\
\hline $\mathrm{B}_{4}$ & $1 / 4$ & $1 / 3$ & $1 / 6$ & 1 \\
\hline
\end{tabular}

The characteristic value is obtained by using excel software. , $W=\left(w_{1}, w_{2}, w_{3}, w_{4}\right)=(0.3657,0.26$ $12,0.2177,0.1555) \mathrm{T}$, Maximum characteristic root $\lambda_{\max }=4.1023$, Consistency index $C I=\frac{\lambda_{\max }-n}{n-1}=0.0341$, Look-up table to $R I=0.89, \quad C R=\frac{C I}{R I}=0.0382<0.1$, the consistency of the matrix is acceptable. You can figure out what the other indices are.

Calculated by the above various primary and secondary indicators of AHP index weight, the secondary index weights of AHP AHP weights are multiplied by its level, obtains the corresponding comprehensive weight, every index weight values shown in the following table.

Table 4 Index weight

\begin{tabular}{|c|c|c|c|c|}
\hline $\begin{array}{l}\text { Secondary } \\
\text { indicators }\end{array}$ & $\begin{array}{r}\text { The } \\
\text { weight }\end{array}$ & Third grade indicators & $\begin{array}{r}\text { The } \\
\text { weight }\end{array}$ & $\begin{array}{l}\text { The overall } \\
\text { weight }\end{array}$ \\
\hline \multirow{3}{*}{ Material storage level } & \multirow{3}{*}{0.3657} & Material damage rate & 0.3656 & 0.1337 \\
\hline & & Equipment failure rate & 0.3323 & 0.1215 \\
\hline & & Maintenance frequency & 0.3021 & 0.1105 \\
\hline \multirow{3}{*}{$\begin{array}{c}\text { Efficiency } \\
\text { management level }\end{array}$} & \multirow{3}{*}{0.2612} & Warehouse utilization & 0.3860 & 0.1008 \\
\hline & & Material transport efficiency & 0.3216 & 0.0840 \\
\hline & & $\begin{array}{l}\text { Equipment and personnel } \\
\text { utilization. }\end{array}$ & 0.2924 & 0.0764 \\
\hline \multirow{3}{*}{ Cost control level } & \multirow{3}{*}{0.2177} & Material turnover. & 0.3125 & 0.0680 \\
\hline & & Credit default rate & 0.3750 & 0.0816 \\
\hline & & Cash flow & 0.3125 & 0.0680 \\
\hline \multirow{3}{*}{ Informatization level } & \multirow{3}{*}{0.1555} & Optimize the organization & 0.2345 & 0.0365 \\
\hline & & Fine service & 0.2814 & 0.0438 \\
\hline & & automation & 0.3376 & 0.0525 \\
\hline
\end{tabular}

From the above calculation results, it can be seen that, on the one hand, due to the different importance of each index to warehouse management, the weight of each index is different. In terms of indicators, the present stage material storage is the key of the warehouse management, still only guarantee the material management, enterprise can benefit, therefore, the index weight in the secondary indexes, the largest followed by efficient management, and then the cost management and informationization level. 


\section{Conclusions}

In this paper, from the level of material storage, efficiency management, cost control, informationization level from four aspects to build the evaluation index system of warehouse management, using analytic hierarchy process (ahp) to determine the index weight and give the corresponding weights of different indexes, warehouse management four guideline values, points out that we should strengthen the material storage level, efficiency management, cost control, and information level of management.

\section{References}

[1] Dj.M. Maric, P.F. Meier and S.K. Estreicher: Mater. Sci. Forum Vol. 83-87 (1992), p. 119

[2] M.A. Green: High Efficiency Silicon Solar Cells (Trans Tech Publications, Switzerland 1987).

[3] Y. Mishing, in: Diffusion Processes in Advanced Technological Materials, edtied by D. Gupta Noyes Publications/William Andrew Publising, Norwich, NY (2004), in press.

[4] G. Henkelman, G.Johannesson and H. Jónsson, in: Theoretical Methods in Condencsed Phase Chemistry, edited by S.D. Schwartz, volume 5 of Progress in Theoretical Chemistry and Physics, chapter, 10, Kluwer Academic Publishers (2000).

[5] R.J. Ong, J.T. Dawley and P.G. Clem: submitted to Journal of Materials Research (2003)

[6] P.G. Clem, M. Rodriguez, J.A. Voigt and C.S. Ashley, U.S. Patent 6,231,666. (2001)

[7] Information on http://www.weld.labs.gov.cn 